\title{
Application Analysis of Interactive Teaching Method on College English Teaching
}

\author{
Tiantian Tang
}

Dalian Ocean University, Dalian, Liaoning, 116300

\author{
Keywords: College English Teaching, Interactive Teaching Method, Application
}

\begin{abstract}
As an integral part of today's innovative teaching methods, interactive pedagogy has been greatly promoted and used in today's college English teaching. Interactive teaching methods in today's college English teaching is an innovative and unique teaching methods. In college English teaching, the application of interactive teaching mode not only arouse students' enthusiasm and enthusiasm to learn English, but also improve the teaching quality of college English education. Therefore, it is a good teaching method in today's innovative teaching methods . On this basis, this article explores the application of interactive teaching methods in college English teaching.
\end{abstract}

\section{Introduction}

Modern teaching theory points out that the teaching process is the process of interaction between teachers and students, active interaction and common development. However, the existing college English (non-English majors) teaching in our country has always been dominated by teachers' classroom teaching. Teachers are the masters of the domination of everything in the classroom, controlling everything and handling all the incidents. This unidirectional single-teacher-dominated classroom makes students feel less happy of intellectual work, alienates students' motivation to learn, eliminates students' learning initiative, imprisons and stifles students' creativity and imagination. In the absence of opportunities for students to participate adequately, the paucity of the world of student experience puts the "knowledge" of learning at an external, sluggish, inertia. At the same time, through years of teaching college English, I deeply understand that this one-way single-teacher lecture-based teaching methods seriously affect the enthusiasm of teachers teaching, teaching effectiveness is often less effective. Therefore, we must constantly update the teaching concept, improve teaching methods, pay attention to cultivating students' creative thinking and maximizing the potential of each student. Learning is an autonomous process. The learner's creative thinking and active cognitive participation are the most active factors in the learning process. It is futile to try to teach what students have to learn by teaching. The purpose of teaching should be to create an environment conducive to learning and conditions. At the same time, improving learners' perceptions of language so that they observe and analyze and reflect on language not only contribute to systematization of language but also develop their ability to observe and analyze problems. They not only learn the language but also learn how to learn. Classroom should not become a place where teachers unipolar performances and students passively listen, but should become an interactive stage for teacher-student interaction, dialogue, communication and inquiry. In order to get rid of the traditional teaching methods and create an interactive platform for teachers and students to teach and learn, I explored and applied the interactive teaching method in the teaching of college English intensive reading.

\section{Interactive teaching method and its advantages}

The so-called interactive teaching refers to teaching and learning in teaching in the process of exchange, communication, consultation, discussion of equality with each other, listen to each other, accept each other, on the basis of mutual honesty, through rational persuasion or debate to achieve the collision of different views, Stimulate the initiative of both teaching, expand creative thinking, in order to achieve a teaching method to improve teaching effectiveness. Compared with the 
traditional teaching of interactive teaching, the biggest difference is that one word: "move." The traditional teaching is the teacher initiative, brain move, mouth move, manual, the result passive, static, quiet mouth, divine calm, thus evolve into indoctrination, a word. The interactive teaching has fundamentally changed this situation, truly "interactive", teachers and students take the initiative to take turns with each other, two-way input, multi-language hall, "I hit you through, you hit me through," and played a harmonious Music chapter. From the pedagogy, psychology point of view, interactive teaching has two advantages: First, give play to the dual initiative. Both teachers and students communicate in two-way, or answer questions or confusion, or distinguish right and wrong. On the one hand, teachers activate students 'independent thinking ability, creative ability or adaptability. On the other hand, teachers should be fully prepared and sensitive to accept the students' challenges . Second, to promote double impact level. Traditional teaching only talk about the influence of teachers, while ignoring the students should have influence. Interactive teaching is an equal discussion between teachers and students on the same topic in different ways. The teachers in the eyes of students have the ability to respect students' independent opinions and solve problems. In the process of communication with students, they form the collision and fusion of mind and reach the concept Convergence. Therefore, in the interactive teaching, teachers should respect the psychological needs of students, listen to their thoughts on the problems, find out their bright spots, form common participation, think together, work together to solve problems, create real psychological resonance, view resonance, thinking Sharing, the same target with the impact of a total of double to promote double effect.

\section{Types of teacher-student interaction analysis}

From a sociological point of view, the classroom is a microcosmic society, and the process of classroom teaching is the process of interaction between various roles (interactive subjects) in the classroom and their unique behavior. The role of classroom teaching is mainly teachers and students. The interaction between teachers and students is also the interaction and interaction between teachers and students. It is essentially a reflection of the relationship between teachers and students. Due to the role relationship between teachers and students in classroom teaching and the wide range of interactive behaviors between teachers and students, they can be analyzed and classified according to these two different standards and perspectives.

Teacher interaction. That teacher behavior points to individual student-teacher interaction, which reflects the relationship between teachers and individual students. The interaction between teachers and students who have the expectation purpose and clear object often manifests as questions and answers, requests and responses, evaluation and feedback, individual counseling, direct contact and so on. This type more clearly shows teachers 'preferences or prejudices against students and students' evaluation and tactics toward teachers. Teacher class interaction. That is, teacher behavior refers to the interaction of teachers and students in the entire student group, which reflects the relationship between the teacher and the student group (class). In teacher-class interactions, students often think that their reaction to teacher behavior is part of a group reaction rather than an individual behavior that is distinct from others. This interaction is common in the organization of teaching, classroom teaching, classroom questions, classroom evaluation process. Team interaction. That is, teacher behavior points to the interaction of student learning groups, which reflects the relationship between teachers and student groups (groups). In the teacher-student interaction, teachers should explain, guide, inspire and evaluate the learning group. In the current classroom of college English teaching in our country, the learning group did not become a meaningful interactive group in teaching. The significance of cooperative learning and the role of the learning group did not get the attention it deserved. Therefore, interaction between teachers and students rarely occurred .

\section{Application of Interactive Teaching Method in College English Teaching}

The key point of interactive teaching is to break the old-fashioned and dull traditional English 
teaching, pay attention to the two-way, interactive, communicative and emotional nature of the process of language learning, stressing both the process and the result so that students through positive thinking and behavioral activities, Achieve the purpose of learning the language and using the language. From the gradual development of students' interest, eliminate the psychological barrier of students, to create relaxed and interactive atmosphere of interest is the best teacher, students interest in learning is to play a core element of consciousness and enthusiasm. For senior students, English varies greatly, making it easy for students to have different feelings of learning English. Students who have passed the Level 4-6 test often neglect further study of English while students with poor English foundation lack study. Confidence in English teaching to bring a greater impact. Teachers should start from the necessity and importance of guiding students to recognize English, actively improve their teaching methods and means, and gradually improve their interest in learning. This is the driving force behind the implementation of interactive pedagogy. Actively create an active and enriching interactive classroom Impacted by the idea of injection, college English teaching is often used traditional full irrigation, the students were "led by the teacher," lack of communication between each other, the students thinking is not active, not thorough understanding, learning tired And tired, teaching effects can be imagined. The introduction of interactive teaching method and bold reform and innovation of teaching methods and means are conducive to giving play to students' subjective initiative and sense of participation, helping to create a student-centered teaching atmosphere, being conducive to conforming to quality education and in line with the development of the times demand.

Interactive teaching method put forward higher requirements for the teachers. Teachers are not only the disseminators of knowledge, but also the planners and hosts of teaching activities. How can the direct effect of teachers directly affect the implementation of interactive pedagogy? English teachers should not only have a solid professional knowledge, but also to learn martial arts to be excellent, high level of English communication. In order to avoid the embarrassment in class, teachers should take a professional mission, extensively cover various fields, expand their horizons, enhance their accomplishments, moisturize their minds, develop their talents, and divert the knowledge sparks and thoughts into the classroom organically, injecting new vitality. Teachers must prepare lessons carefully and prepare carefully. Interactive classroom teaching more organized, involving a wider range of knowledge, teaching more flexibility. Teachers as classroom organizers, to be handy, must be carefully prepared before the class, not only should be coherent, but also continue to collect, accumulate and update the relevant professional material, to prepare some specific examples to enhance students' professional knowledge Perceptions. In addition, the teacher should also be designed according to the specific teaching content and characteristics in the classroom before the class form, classroom scenes and procedures, and pay attention to grasp the process direction, pace, progress, both in the field as the protagonist, but also allow students to become the protagonist, Promote the classroom in an orderly manner.

\section{Conclusion}

To sum up, in interactive teaching, we must follow the principle of student's subjectivity, people-oriented, believe in students, boldly let go, and arouse students' enthusiasm for learning. In the multi-level, diversified and reciprocating contact between teachers and students, the students 'thinking is more active, fully mobilize the consciousness, initiative, enthusiasm and participation of all students and cultivate the students' independent thinking and innovative awareness. In the concrete implementation, we also find that there are some problems in the teaching of students, such as lack of preparation, lack of standardization of language, lack of control over teaching contents and time control, etc., and further discussion and amendment in future teaching and research are needed.

\section{References}

[1] Wen Ping. Constructivism-based interactive teaching practice between teachers and students [J]. 
Journal of Guangxi Normal University, 2003, (3).

[2] Zhang Haiyan. Application of interactive teaching method in English extensive reading teaching [J]. Liaoning Normal University, 2005, (6).

[3] Ma Liangquan. Discussion on Interactive Teaching Method [J] .Journal of Qinghai Teachers College, 2006, (3-4).

[4] Yuan Weixin. On teacher-student interaction in teaching process [J]. Educational Theory and Practice, 2002, (1).

[5] Zhang Lin, Chen Ni, Zhang point. Application of Interactive Teaching Method in Professional English Teaching [J]. Journal of Xiangtan Normal University, 2005, (6). 